\title{
Chapter 13: Localism and neighbourhood planning in Australian public policy and governance
}

\author{
By Paul Burton, Cities Research Centre, Griffith University
}

\section{Introduction}

Localism is often used in confusing and contradictory ways in Australian political debate and policy discourse. While many State and Territory governments extol the virtues of devolving responsibility for planning and service delivery down to local governments, they show no sign of relinquishing their constitutional authority over local government or of pressing for further devolution to more localised communities. State and Territory governments continue to exercise their constitutional authority over local government in regulating their powers, responsibilities and finances and most symbolically in enforcing the amalgamation of local councils in the name of efficiency and effectiveness, often in the face of staunch opposition from the councils concerned (Brown and Bellamy, 2006; Kembray, 2015; Sansom, 2015). While this may frame localism as the application of the subsidiarity principle in practice, it reflects also an increasingly complex system of multi-level governance based on a distinctive Australian system of federalism. This system does not yet give any constitutional recognition to local government but provokes considerable debate about overlapping responsibilities, bureaucratic duplication and cost-shifting. Because most local governments in Australia cover relatively small populations, there is little or no political pressure for them to devolve powers and responsibilities to even more local levels, but this is not to say that they are not increasingly conscious of their statutory obligations and political commitments to develop more extensive and effective programs of public participation and community engagement.

Paradoxically, while the colonial predecessors of the States and Territories agreed to the formation of a federal Commonwealth of Australia in 1901 and those State and Territory governments now determine the nature of local government in their jurisdictions, there are growing calls to resolve many of the problems of three-tier federalism by abolishing the 
States and Territories in the name of localism (Twomey \& Withers, 2007). However, it is unlikely that such a radical reform will gain much political traction in the foreseeable future. Among the challenges for advocates of localism in Australia are the problems of political and bureaucratic capacity in an extremely diverse pattern of local governments, the nature of relations between levels of government and between adjoining councils, and problems of scale in a very large country with a relatively small but spatially concentrated population. This chapter explores these challenges, looking critically at the differences between the rhetoric and the reality of localism in practice. It uses examples drawn mainly from the state of Queensland, but places these in comparative context with other Australian and overseas experience.

\section{Logics of localism}

In their introduction to a special issue of Policy Studies on 'localism', Evans, Marsh and Stoker (2013) propose a three-fold classification of localism in Westminster-style democracies: representative, managerial and community-based. While these may be analytically distinct, they claim that in practice what counts is the particular mix of one or more of these types in any particular locality. Nonetheless, they suggest that of the three types, representative localism has tended to dominate media and public debate as it is preoccupied with electoral competition and the success or failure of candidates, parties or factions. This is certainly the case in Australia where extensive and often intense media scrutiny is concentrated on the federal and state levels of government and only occasionally on local levels, although the political machinations and performance of local government remains a staple of local newspaper coverage. One could in fact advance an argument of exceptionalism in which local governments only receive media attention outside of their locality when faced with extra-ordinary events such as natural disasters (in Australia typically floods or bushfires) or instances of political corruption or malfeasance, although this is not, of course, an argument about local government confined to Australia. Finally, political leadership in Australian local government is subject to significant variation with the leaders of local councils (typically called Mayors) directly elected in some places and selected from among the set of local councillors in others. The legitimacy and efficacy of these different arrangements remains subject to debate, but some of the larger urban 
councils are moving closer to the Queensland model of requiring all to have directly elected Mayors (Burton, in press).

Managerial localism consists of the delegation of some powers and responsibilities from superordinate to subordinate bodies, within a specific regulatory framework. In Australia this in fact characterises the entire system of local government in which powers and responsibilities given to local authorities could be taken away by State and Territory governments if they choose. In Queensland, for example, a set of Priority Development Areas (PDAs) has been established by the State Government with a streamlined and focused approach to development assessment to stimulate localised economic growth. PDAs are not imposed on local governments against their will and in most cases are actively sought by them, but they can involve the loss of development assessment powers in the designated area. The operation of these PDAs is critically reviewed below.

The third stand of localism is described by Evans et al as 'community localism' and entails the devolution of certain rights and responsibilities by government bodies directly to citizens as individuals and in groups. Although there may be instances of this in some European countries (Kersting \& Vetter, 2013), it is not commonplace in Australia. State and Territory governments can conduct referendums and non-binding plebiscites, seen as particular instances of devolution in an otherwise representative system of government, but these are not common. Public participation or community engagement in certain aspects of local service planning and, of course, in land use and development planning is much more widespread. Again, this often takes the form of bilateral engagement between individual citizens and government representatives when responding to policy or development proposals or completing local opinion surveys, but it sometimes involves more collective forms. At the local level, public meetings are commonplace while more structured events such as focus groups or design charrettes are less common but growing in popularity. Collective visioning events are sometimes organised at the State or Territory level, and in 2013 the Queensland government of Premier Campbell Newman embarked on an extensive program of community engagement. In preparing the Queensland Plan, the government held a variety of events including two major summits at which hundreds of people were invited to participate in preparing a shared vision. The government claimed '..it resulted in the largest community engagement activity of its kind ever undertaken in Queensland with 
individuals and groups from every corner of the state taking part.' (Queensland Government, 2015) but for some it was an expensive exercise in manipulation that occupied one of the lowest rungs on Arnstein's (1969) ladder of participation (Remeikis, 2015). At the Federal level, the government of Prime Minister Kevin Rudd held the Australia 2020 Summit in April 2008 to 'help shape a long term strategy for the nation's future'. This saw 1000 of 'Australia's brightest minds' gather to discuss future prospects and priorities across ten policy fields and, again, represented a collective form of public participation, but one which was highly controlled in terms of its membership and agenda.

\section{A brief history of local government in Australia}

While local governments prefigure Australian State and Territory governments and indeed the Federal government of Australia, they now constitute the least powerful of all three levels of government and are dependent on their respective State or Territory government for their continued existence and the definition of their powers.

The first directly elected local council was formed in 1840 with the creation of the Adelaide Corporation to manage the affairs of that emerging city of free settlers. However, within three years it had been suspended and the city was subsequently run by a small group of Aldermen commissioned by the colonial government. Morton (1996) calls this the beginning of a 'continuously abrasive relationship' between local, state and federal governments in South Australia. Across the country at large and across the decades this relationship between the three levels of government has never been entirely harmonious and the latest attempt to secure 'financial' recognition for local government in the Constitution foundered (as described below) in the aftermath of the election of the Coalition federal government in 2013.

Local governments in Australia have typically been given but have also embraced what might be termed a minimalist position: collecting local rates to provide basic but important local services and facilities, such as the maintenance of roads and bridges as well as the collection and disposal of waste. These can be described as mainly property-based rather than social services and reflect the fact that the liability to pay rates and the right to vote were tied initially to property ownership and reflected therefore the interests and needs of 
property owners. But throughout the $20^{\text {th }}$ century the role and scope of local government steadily expanded, first through the acquisition of powers to regulate development and then through providing more by way of social services to meet the needs of the full range of its local citizens. There remains, nevertheless, a tension between those wishing to limit the powers and hence the revenue-raising obligations of local government and those promoting greater local government intervention across a broader spectrum of local activities.

In comparison with local governments in the UK, Australian local governments are much more limited in their scope, with responsibility for education, social services, health and housing and policing all resting with State and Territory governments. As these are services that have a distinctly local dimension, local councils are not well placed to present themselves as the self-evident institutions of localism. This is not to say that many councils do not pursue these ambitions or that they are not seen in this light, but they are doing so without the opportunity or responsibility to intervene in a number of areas that are usually associated with localism in other settings.

Politically, Australian local government is characterised as much by parochialism as by localism and while there is little evidence of concerted and systematic attempts to give more power to the people in localities, there is in most cases an enduring commitment among local politicians to their locality. In other words, many local councillors see themselves as the principal conduit of local opinion and remain suspicious of public participation and community engagement initiatives that appear (to them at least) to have the potential to undermine their role and responsibility as the foremost and formal representative of the people of their area. Some of the larger councils have developed more systematic approaches to neighbourhood level planning, but it is important to remember that many councils in Australia serve very small populations, often scattered over very large areas and that notions of neighbourhood politics developed in metropolitan areas may not apply in remote and rural areas.

Nor is there evidence of any concerted campaign in Australia to transfer statutory responsibilities from the State and Territory to more local levels, either the local government or even smaller spatial scales. The Australian Local Government Association (ALGA) is the peak national body for local government and is a member of one of the important national intergovernmental bodies - the Council of Australian Governments 
(COAG), which brings together the Prime Minister, all Premiers and Chief Ministers of States and Territories and the President of ALGA. ALGA has campaigned for a number of years for local government to be recognised in the Constitution. Following recent High Court rulings, the constitutional authority for the Federal government to make payments to local government has been called into question. This is significant as local governments claim their ability to meet their statutory obligations, let alone pursue additional local goals, is now severely compromised by a structural funding problem. ALGA presents their case for this reform as follows:

Of course, councils can't do the job of meeting the community's needs on their own. Local government must work in partnership with the other two levels of government-the Federal Government and the States and Territories-to deliver services and infrastructure at the local level. Providing the increasing range of services expected by the community is often beyond the limited resources of local communities, local ratepayers and therefore most councils. Grants from other levels of government are critical. And it is reasonable to expect that some of the taxes paid to the State and the Federal Government will be used to provide services and infrastructure at the local level. (ALGA, 2012: 2)

Australian local governments have become increasingly reliant in recent years on Federal grant programs to cover local investment, especially in road maintenance and improvement. The constitutional standing of some of these funding regimes has been called into question (Hogg and Lawson 2014), and this has provided the impetus for a campaign to change the Constitution to recognise the existence of local government and thereby allow it to receive grants directly from the Federal government. In 2007 the newly elected Prime Minister, Kevin Rudd promised to progress the issue of constitutional recognition and considerable effort by an ALGA Expert Panel and a Parliamentary Joint Select Committee on Constitutional Recognition saw the passage of the Constitution Alteration (Local Government Bill) 2013, with a referendum scheduled to occur in the latter half of that year. The reinstatement of Kevin Rudd as leader of the Australian Labour Party and hence as Prime Minister (replacing Julia Gillard) in June 2013 saw a snap election called for September which effectively rendered a referendum impossible in its intended timeframe. The Coalition government led by Tony Abbott elected in September 2013 subsequently announced it would not pursue a referendum of this type in the foreseeable future and the 
new (September 2015) Coalition Government led by Prime Minister Malcolm Turnbull has given no indication to date that this will be a priority in its policy agenda.

Thus, an important element of any broader movement to strengthen the position of local government in Australia and to practically advance a localist agenda has been dropped and is unlikely to become a priority of any Federal government in the foreseeable future. This is not to say that the Federal government does not continue to provide financial support to local government across the country according to the principle of horizontal fiscal equalisation. In Queensland, for example, \$450 m of (Federal) Financial Assistance Grant was received by all 77 local government bodies in the State in 2015/16, with the City of Gold Coast receiving $\$ 18.4 \mathrm{~m}$ and Brisbane, $\$ 38.3 \mathrm{~m}$, but these remain relatively small components of their total budgets. For smaller councils and especially those with small populations compared to their land areas, these Commonwealth funds can however represent a more significant source of assistance in maintaining a dispersed network of minor roads and bridges vulnerable to the effects of flooding.

\section{Localism in practice: Australian cases}

One of the overriding features of Australian local government is its variety, as each State and Territory has its own legislative base for local government, its own traditions and history and a distinctive geography over which their local government system must operate. It is, therefore, unwise to see localism in Australia in general or national terms, and important to appreciate the significant variation across the States and Territories. This section presents four short case studies of localism in practice drawn principally from one State, Queensland and one from the Northern Territory. The Queensland cases illustrate different manifestations of localism: how parts of some local government jurisdictions are deemed worthy of special forms of intervention; the development of neighbourhood planning mechanisms in an uncharacteristically unified large metropolitan council; and the allocation of substantial budgets to divisional councillors in another large city. The Northern Territory case touches also on important issues of Indigenous local politics which are often neglected in Australian local government studies (Morton, 2012). 
The Economic Development Act, 2012 enables the Queensland government to work with local governments in the State to promote economic development for the benefit of local communities. One way it does this is through the designation of Priority Development Areas (PDAs) for particular localities, which results in the removal of the designated area from the provisions of the Sustainable Planning Act (SPA), 2009. In short the designated area becomes subject to a different planning regime; a more streamlined regime that has fewer regulatory requirements than would apply under the SPA. Responsibility for preparing and implementing plans in a PDA can be delegated by the Minister for Economic Development Queensland to any one of a number of bodies, including a Local Representative Committee or the local council in whose area the PDA falls. The purpose of this initiative, which has some similarities with urban development corporations in other parts of Australia and overseas, is to encourage local economic development by speeding up the assessment process and relaxing regulations. As an explanatory brochure published by Economic Development Queensland (the state government body that oversees this process) says,

The process for development assessment differs significantly between the Economic Development (ED) Act and SPA, due to the removal of the state agency referral process and appeals against development assessment decisions under the ED Act. The removal of state agency referrals is recognition of the collaboration with state agencies during the plan making process to resolve issues. The lack of an appeals process is to avoid potential delays to development within PPDAs/PDAs, which undermines the objectives of the ED Act to facilitate economic development (EDG, 2015: 3)

The logic of this initiative is that the declaration of a PDA will accelerate development, provide greater certainty to the property market, in some cases unlock the development potential of government land and help particular major projects succeed. In the City of Gold Coast for example two PDAs have been declared: for the neighbourhood of Southport, which the city council recently designated as its official central business district; and the old Parklands showgrounds next to Griffith University's Gold Coast campus, which will become the Athletes Village for the 2018 Commonwealth Games and subsequently part of the Gold Coast Health and Knowledge Precinct. Whereas the Parklands PDA is managed by Economic Development Queensland, planning in the Southport PDA remains the responsibility of a specialist team within the City of Gold Coast council. 
As noted above, what makes PDAs particularly noteworthy is the fact that responsibility for managing each one can and does vary according to local circumstances and that in some cases responsibility is retained by the local council. Indeed, PDAs are only declared with the support of local councils and are not imposed on them by the state government. In practice, if PDAs work in accordance with their principles, then residents will have lost some capacity to influence patterns of development in their locality as the PDA regime restricts third party appeal rights and shortens the period in which development applications must be processed. To date 26 PDAs have been declared and while many relate to large greenfield sites with few existing residents, there is little or no evidence of concerted opposition to them in general or in particular places and in many cases the general public is likely to be unaware of their existence. While the logic of their existence is based on a critique of the efficacy of normal local government planning regimes, local councils do not appear unduly concerned with PDAs either and tend to see them as useful vehicles for expediting development and growth in their area. In other words, a pragmatic acceptance of the benefits of local economic development typically outweighs any concern about the lack of local autonomy.

\section{Neighbourhood Planning in Brisbane}

Neighbourhood planning is not a commonplace term or indeed one that is used with any degree of consistency across Australia. Sometimes it refers to the preparation of local area plans within cities, which usually have some statutory weight and are used in the assessment of development applications; sometimes it refers to the more general process of preparing urban design guidelines for particular neighbourhoods. It rarely refers to more comprehensive programs of neighbourhood (or sub-municipality) planning for a range of local services, as it does in the UK and some other European countries. One exception to this is the process of neighbourhood planning in Brisbane.

In Brisbane, the city council decides which neighbourhoods within the city should have their own neighbourhood plan and once approved these become part of the panoply of plans regulating development across the city. So, the Brisbane City Plan 2014 provides the overall planning framework for the whole city over a 20 year period but this is supplemented by 72 neighbourhood plans. These neighbourhood plans are concerned principally with land use planning and development assessment address social, economic or environmental 
objectives mainly through land use planning processes rather than through more direct intervention and spending programs. Neighbourhood plans must be consistent with the City Plan, which always takes precedence in any disputes, just as city plans must be consistent with the principles of any State plan and remain constitutionally subservient to it. Public participation and community engagement principles are certainly applied in this neighbourhood planning processes, as there is a statutory obligation to do so. In Brisbane and elsewhere some councils approach these public participation obligations enthusiastically and imaginatively, but not all do so. While there is little empirical and comparative research on the impact of public participation in practice, it is likely that variation in enthusiasm and imagination reflects a number of factors. Local councillors and mayors who are more politically mature and secure in their roles are more likely to see the benefits of public participation in local policy and decision making, while others may see it as a threat to their standing and role as representatives. The great variation in size and hence capacity of local councils also influences their disposition to public participation beyond the minimal statutory obligations and often relies on the enthusiasm of one or more key individuals. Of course, the existence of different levels or spatial scales of planning (neighbourhood and city-wide) also leads typically to different scales of participation and engagement and hence to the possibility of conflicting outcomes of these processes. In Brisbane this has seen public debate and political conflict around competing planning principles that have emerged from neighbourhood and city-wide planning and participatory processes (McKechnie, 2015) and illustrates how greater participation does not necessarily lead to greater consensus in policy and decision making processes.

\section{Divisional budgets in the City of Gold Coast}

Paradoxically, in most (but not all) local government areas councillors are elected to represent local divisions and only mayors are elected at large with an unambiguous responsibility to take a strategic view of their whole jurisdiction. Divisional councillors are, of course, expected also to act in the best interests of the council area as a whole, but in practice there are often incentives to behave parochially. In the City of Gold Coast, for example, each of the fourteen divisional councillors is allocated an annual divisional budget (currently worth approximately $\$ 700,000$ ) to spend on local projects that might otherwise fail to receive support from city-wide budgets. While this undoubtedly gives divisional 
councillors significant capacity to respond to local needs and issues and hence to practice localism, it also fosters concerns about the hoarding of funds and pork barrelling that are frequently aired in the local media (eg Gold Coast Bulletin, 7 May 2014 \& 21 April 2015). Councillors, unsurprisingly, see things rather differently and speak of the value of these funds in balancing the 'whole of city' perspective that characterises most of their work. Indeed in its latest budget the City Council agreed to fund a city-wide kerbside collection program which had previously only been offered in some areas and supported by some Councillors from their divisional budgets.

\section{Supershires in the Northern Territory}

The Northern Territory only achieved a degree of self-government in 1978 when the Northern Territory Legislative Assembly was granted a set of delegated powers and responsibilities by the Commonwealth Parliament. One of its first actions was to pass a local government act to create a new system of local government comprising municipal councils in urban areas and a disparate set of 'community government councils' elsewhere in what is a very large but sparsely populated jurisdiction. The Northern Territory differs from the other States and Territories in that almost $30 \%$ of its population of 231,000 consists of Indigenous people, compared with 3\% for the whole of Australia (ABS, 2011). The politics of local government in the Northern Territory is, therefore, inextricably a politics of indigeneity and perennial settler attitudes to place, size and efficiency in the delivery of services often run counter to indigenous perspectives and principles.

In the name of greater efficiency and in response to increasing concerns with the 'highly dispersed and differentiated system of local government' in which up to half the remote (Indigenous) area councils were judged to be high risk or dysfunctional, a simpler system was proposed comprising municipal councils for the main towns and cities and new 'regional shires' for the rest of the Territory (Sanders, 2013: 477). In late 2008 seven large remote area shires, or 'supershires' had been fully established but as Sanders (2013) argues, for two main reasons these came to represent a 'loss of localism'. First, in four of the new shires in the south of the Territory the headquarters of the councils were located outside their own boundary. Second, a substantial democratic deficit emerged as a repeating single member election system saw councillors in some wards elected from a very small number of settlements while many more remote settlements were unrepresented. Moreover, the new 
system saw a clarification of the role of elected councillors vis a vis appointed officers in which the direct relationship that had existed previously was transformed into one based on a more traditional separation of powers between policy making and implementation. Sanders (2013: 485) suggests that this contributed to some representatives disengaging from the bodies to which they were elected because they were no longer able to work closely with officers in dealing with local issues and trying to solve the problems of local residents. It also reflects a possible point of difference between settler and Indigenous perspectives on the nature of local government and the relations between elected and appointed officials.

\section{Conclusions}

In countries like the UK an enduring challenge for territorial politics has been to mount a plausible case for the creation of a new tier of government between the central and the local, one that balances arguments about efficiency with more subjective notions of regional identity, sense of attachment and engagement with government. To date this has proved impossible and the 'regional agenda' appears to have all but disappeared. Instead, arguments for giving greater power to local governments and for devolving significant power and responsibility to even lower levels, such as neighbourhoods or parishes, have achieved greater prominence and political traction.

In Australia this regional challenge was met, constitutionally at least, in the creation of the States and Territories and in their agreement at the start of the $20^{\text {th }}$ century to form a Federal government to preside over the Commonwealth of Australia. This three-tier system provides, in theory at least, the opportunity to distribute responsibilities for government among the different tiers in such a way as to reflect efficiencies and economies of scale in the delivery of services and to maintain a sense of attachment and allegiance to long standing territorial entities. But in practice there is widespread public dissatisfaction with contemporary Australian federalism and a belief that political responsibilities are blurred, costs are shifted and services duplicated or avoided because of this arrangement. There is no evidence that the public at large would like to see the introduction of a fourth tier of government through any process of giving more powers and responsibilities to neighbourhood scale entities. The Australian Constitutional Values Survey suggests that in 
general, Australians are happy with their local governments retaining a comparatively minimalist position, focusing on 'roads, rates and rubbish' and not taking on an expanded role that might test significantly their competence and capacity. Whether this is also the case for large metropolitan councils such as Brisbane and the Gold Coast and whether the plethora of small councils that exist in most of the capital cities should be amalgamated is not so clear at this stage.

The case studies presented above highlight a number of other enduring issues associated with Australian localism, or perhaps more accurately with relations between different levels of government in which the precise degree of devolution of powers and responsibilities between levels is to some extent negotiable. These issues include the degree of trust that exists between levels of government, which in turn is related to perceptions of competence and capacity, and to the size and efficiency of governmental units and the extent to which these units promote a sense of attachment and democratic engagement. There is a widespread sense that local councils should do all they can to contain local taxation in the form of rates and building economies of scale through amalgamation is one way, albeit contested (Byrnes and Dollery, 2002) of achieving this. On the other hand, proposals to amalgamate local councils in the name of greater efficiency often bring to the surface strong local feelings about the importance of place and in some cases the de-amalgamation of councils is pursued even when local citizens are made aware the significant costs of doing so (Drew and Dollery, 2014). Similarly, there is very little prospect of the state capital cities of Sydney, Melbourne, Perth or Adelaide choosing to take the path adopted by Queensland in 1925 when the City of Brisbane was formed through the merger of 20 previously separate local authorities. Although the city council's jurisdiction now includes only half the population resident within the greater metropolitan area (the Greater Capital City Statistical Area) it remains the only state capital city in Australia with a relatively consolidated council and stands in contrast to Sydney with 35 councils and Melbourne with 28.

There are few calls for the creation of new forms of neighbourhood governance at the submunicipal level, indeed some have even argued that the widespread practice of electing local councillors for divisions (or wards) on a first-past-the-post basis should be replaced by elections at large using some form of proportional voting so as to avoid what is seen as an unduly parochial aspect of Australian local government (Tan \& Grant, 2013). This is not to 
say that many local citizens would not welcome a more active role in local politics and decision making through programs of community engagement. However, as noted above, the benefits of greater public participation and community engagement in local governance remain, in Australia as elsewhere, mostly articles of faith rather than empirical certainties. In summary, the enthusiastic application of localism and neighbourhood planning seen in the UK and some other European countries is not so evident in Australia. This may be because of the substantial variety in scale and capacity among Australian local governments and because each of the eight States and Territories has its own local government legislative framework. The balance of powers and responsibilities is also different in the three-tier Australian system and local governments typically have a much more narrow range of responsibilities than their European counterparts. While public trust in Federal and State governments is affected (often adversely) by volatility in leadership and control and there is widespread dissatisfaction with duplication and cost-shifting between the different levels of government, there has not been a pronounced and concerted attempt to devolve power to the people either at the local government level or even closer to them at the neighbourhood level. Localism is, therefore, a principle yet to be applied with any degree of enthusiasm in Australia. 


\section{References}

Arnstein,R. (1969) A Ladder of Citizen Participation, Journal of the American Institute of Planning, 35 (4), 216-224

Australian Bureau of Statistics (ABS) (2013) Estimates of Aboriginal and Torres Strait Islander Australians, June 2011, accessed 5/10/15 at: http://www.abs.gov.au/ausstats/abs@.nsf/mf/3238.0.55.001

Brenner N and Theodore N (2002) Cities and the geographies of 'actually existing neoliberalism', Antipode, 34, 349-79

Brown, A.J. (2014) Australian Constitutional Values Survey 2014, available at: https://www.griffith.edu.au/_data/assets/pdf_file/0015/653100/Constitutional-ValuesSurvey-Oct-2014Results-2.pdf

Brown, A.J. and Bellamy, J. (eds) (2006) Federalism and Regionalism in Australia: New Approaches, New Institutions, Canberra: ANU E Press

Burton, P. (2009) 'Conceptual, theoretical and practical issues in measuring the benefits of public participation' Evaluation, vol 15, no 3, pp 263-284

Burton, P. (2014) 'From white shoes to bold futures: the neoliberalisation of local government in an Australian city?', Urban Studies, vol 51, no 15, 3233-3249, DOI: 10.1177/0042098014540944

Burton, P. (in press) 'Popular leaders or rats in the ranks? Political leadership in Australian cities', in D. Sweeting (ed) Directly elected mayors in urban governance: impact and practice, Bristol: Policy Press

Byrnes, J. and Dollery, B. (2002) 'Do economies of scale exist in Australian local government? A review of the empirical evidence', Working Paper Series in Economics 20022, Armidale: University of New England

Cahill, D. (2013) Ideas-centred explanations of the rise of neoliberalism: a critique, Australian Journal of Political Science, 48:1, 71-84

Daley, J. and Barlow, M. (2012) Regional Growth Patterns: Evidence from the Latest Census, Edited transcription of Grattan event, Melbourne, 27 November 2012

Drew, J. and Dollery, B. (2014) Separation anxiety: an empirical evaluation of the Australian Sunshine Coast Regional Council de-amalgamation, Public Money \& Management, 34:3, 213-220, DOI: 10.1080/09540962.2014.908032

Easthope, H. (2009) The fourth tier of governance: Managing the future of our cities, paper presented at the 2009 State of Australian Cities conference, Perth and available at: http://apo.org.au/node/60112 
Edelman (2014) Edelman Trust Barometer Executive Summary, available online at: http://www.edelman.com/insights/intellectual-property/2014-edelman-trustbarometer/about-trust/executive-summary/

Evans, M., Marsh, D. and Stoker, G. (2013) Understanding localism, Policy Studies, vol 34, no 4, 401-407

Evans, M., Stoker, G. and Marsh, D. (2013) In conclusion: localism in the present and the future, Policy Studies, vol 34, nos 5-6, 612-617

Featherstone, D., Ince, A., Mackinnon, D., Strauss, K. and Cumbers, A. (2012), Progressive localism and the construction of political alternatives. Transactions of the Institute of British Geographers, 37: 177-182. doi: 10.1111/j.1475-5661.2011.00493.x

Hogg. M. and Lawson, C. (2014) The watershed for Commonwealth appropriation and spending after Pape and Williams?, Australian Journal of Administrative Law, 21, 145-155

Kembray, M. (2015) Council mergers: expert adviser Graham Sansom slams merger proposals, Sydney Morning Herald (online editon), 20 December, accessed on 22/12/15 at: http://www.smh.com.au/nsw/council-mergers-expert-adviser-graham-sansom-slamsmerger-proposals-20151218-glrg0o.html

Kersting, N. \& Vetter, A (2013) Reforming Local Government in Europe: closing the Gap between Democracy and Efficiency, Wiesbaden: Springer

Markus, A. (2014) Trust in the Australian Political System, Papers on Parliament No. 62, Canberra: Parliament of Australia

McKechnie, K. (2015) Brisbane City Council criticised over breaching own planning requirements, $A B C$ News website, 4 May, accessed on 23/12/15 at: http://www.abc.net.au/news/2015-05-04/brisbane-city-council-criticised-over-planningrequirements/6444070

Morton, A. (2012) Role and Expectations of Rural-Remote and Indigenous Local Government, Australian Centre of Excellence for Local Government, Sydney: University of Technology, Sydney

Morton, P. (1996) After Light: A History of the City of Adelaide and its Council, 1878-1928, Adelaide: Wakefield Press

Peck J and Tickell A (2002) Neoliberalizing space, Antipode, 34, 380-404

Remeikis, A. (2015) Jackie Trad planning the plan to plan our future, Brisbane Times (online edition), 28 July, accessed on 22/12/15 at:

http://www.brisbanetimes.com.au/queensland/jackie-trad-planning-the-plan-to-plan-ourfuture-20150728-gilxm3.html

Sanders, W. (2013) Losing localism, constraining councillors: why the Northern Territory supershires are struggling, Policy Studies, vol 34, no 4, 474-490 
Sansom, M. (2015) NSW council sackings threat real: local government expert, Government News (online edition) 11 November, accessed 22/12/15 at:

http://www.governmentnews.com.au/2015/11/nsw-council-sackings-threat-real-localgovernment-expert/

Tan, S. F. and Grant, B. (2013) Local Representation in Australia: A review of the legislation and the literature, Sydney: Australian Centre of Excellence for Local Government, University of Technology Sydney

Twomey, A. \& Withers, G. (2007) Australia's Federal Future: Delivering Growth and Prosperity, Federalist Paper 1, Sydney: Council for the Australian Federation

Young, K., Gosschalk, B. and Hatter, W. (1996) In search of community identity, York: Joseph Rowntree Foundation 